九州大学学術情報リポジトリ

Kyushu University Institutional Repository

Estimation of the Thermal Decomposition and Analysis of Evolved Species and Char of Wood Preservatives Using Thermogravimetric Analysis Combined with Spectrometric Techniques

Lin, Han Chien

Department of Forest Products Science, College of Agriculture, National Chiayi University

Murase, Yasuhide

Faculty of Agriculture, Kyushu University

https://doi.org/10.5109/9346

出版情報: 九州大学大学院農学研究院紀要. 52 (2)，pp.371-380，2007-10-29. Faculty of Agriculture, Kyushu University

バージョン：

権利関係 : 


\title{
Estimation of the Thermal Decomposition and Analysis of Evolved Species and Char of Wood Preservatives Using Thermogravimetric Analysis Combined with Spectrometric Techniques
}

\author{
Han Chien LIN ${ }^{1}$ and Yasuhide MURASE ${ }^{2}$ \\ Laboratory of Wood Material Technology, Division of Biomaterial Science, Department of \\ Forest and Forest Products Sciences, Faculty of Agriculture, \\ Kyushu University, Fukuoka 812-8581, Japan \\ (Received June 30, 2007 and accepted July 17, 2007)
}

\begin{abstract}
Three types of wood preservatives, creosote oil (Creosote), chromated copper arsenate (CCA-3) and ammoniacal copper quats (ACQ-1) were studied, first by using thermogravimetric analysis (TGA) under different heating rates $\left(5\right.$ or $40^{\circ} \mathrm{C} / \mathrm{min}$ ), and then by using thermogravimetric analysis with infrared spectrometry (TGA-IR) and energy dispersive X-ray spectrometry (EDX). The results obtained from the TGA tests found that the decomposition temperature of each of the preservatives for the heating rate at $5^{\circ} \mathrm{C} / \mathrm{min}$ was lower than that at $40^{\circ} \mathrm{C} / \mathrm{min}$. Regardless of different heating rate, the char (wt \%) of the CCA-3 was more than that of the ACQ-1, and the amount of char for the Creosote was lower than that for either of the water-based preservatives. The IR response of all preservatives in the TGA-IR tests showed that at a heating rate of $5^{\circ} \mathrm{C} / \mathrm{min}$, the absorbance of Creosote and ACQ-1 was higher than that of CCA-3. This indicated that the concentration of evolved species of CCA-3 was less than that of Creosote and ACQ-1. However, at a heating rate of $40^{\circ} \mathrm{C} / \mathrm{min}$, the absorbance of CCA-3 and ACQ-1 was higher than that of Creosote. Considering the decomposition step (thermal time or temperature) at different heating rates in the TGA tests and the IR response from the TGA-IR analysis, the results obtained showed that at the slow-heating regime, the concentrations of $\mathrm{CO}_{2}$ produced by Creosote and ACQ-1 were higher than that of CCA-3, but at the fast-heating regime, the concentration of $\mathrm{CO}_{2}$ for ACQ-1 was higher than that of Creosote and CCA-3. The EDX analysis of all preservatives showed that the main element of the char for Creosote was C (82.75\%) after combustion. The char of CCA-3 had an amount of Cr (34.99\%) that was obviously more than that of $\mathrm{As}(11.89 \%)$ and $\mathrm{Cu}(16.69 \%)$ due to $\mathrm{Cr}$ being a stable element during combustion. The char of ACQ-1 left a high amount of inorganic metal elements, such as $\mathrm{Cu}$ (50.14\%). These results, when compared to the chemical ingredients of all preservatives, enabled us to point out the kinds of evolved species for referencing the thermo-decomposition processes of the preservatives. The use of TGA for analyzing the thermal properties of three types of preservatives, in combination with TGA-IR and EDX analysis, has led to useful results, regarding the identification of thermal decomposition products (evolved species and char).
\end{abstract}

\section{INTRODUCTION}

Extra protection is needed when wood is exposed to adverse environments. This is because wood becomes subject to degradation by a variety of natural causes when left untreated in many outdoor applications. For the past few decades, wood can be protected from the attack of decay fungi, harmful insects, or marine borers by applying chemical wood preservatives with long-lasting results (Connell, 1991). Wood preservatives can be divided into two general classes: (1) oilborne (oil-based) preservatives, such as coal-tar creosote (creosote oil) and petroleum solutions of pentachlorophenol and (2) waterborne (water-based) preservatives that are applied as water solutions, such as chromated copper arsenate (CCA) and ammoniacal copper Quats (ACQ) (Ibach, 1999). However, environmen-

Laboratory of Environment Functional Materials, Department of Forest Products Science, College of Agriculture, National Chiayi University, Chiayi, Taiwan, ROC. Corresponding author (E-mail: alexhlin@mail.ncyu.edu.tw)

${ }^{2}$ Laboratory of Wood Material Technology, Division of Biomaterial Science, Department of Forest and Forest Products Sciences, Faculty of Agriculture, Kyushu University, Japan. tal concerns have drastically changed the active ingredients of wood preservatives, resulting in restricted use (Sanders and Windom, 1980; Sanders and Riedel, 1987; Weis and Weis, 1992a, b, 1996, 1999; Cooper, 2001), especially since substantial amounts of CCA or creosote oil remain in the wood for many years and the disposal of scrap wood has become an ever increasing problem (Cox, 1991; Cooper et al., 2003; Solo-Gabriele et al., 2003). Some years ago, alternative copper-based preservatives, ACQ, comprised of a combination of copper and organic biocides were developed relatively, and are being used increasingly for wood preservation in many countries.

At the same time, there is an increasing concern worldwide about the disposal of preservative-treated wood products after use (Cooper, 1994). Discarded wood treated with any of these above mentioned wood preservatives will need to be reused, recycled, or disposed of in an environmentally acceptable manner (Ibach, 1999; Cooper, 2001; Lin et al., 2006). The waste stage of preservative treated woods also has a very significant impact on its life cycle assessment results (Esser et al., 2000). Preservative-treated woods, however, are not included in the wood recycling industry, basically because of technical problems and regulatory concerns, and the same applies to waste wood manage- 
ment (Falk, 1997). The common waste disposal options for spent preserved wood are combustion and landfilling (Kuwahara, 1996; Jang, 1997; Kobayashi et al., 2000). Even though wood is considered an ecological material (Takahashi et al., 1995), it is necessary to determine the thermal composition of these preservatives during combustion, including such things as, decomposition temperature, compounds emitted, total amount of volatiles evolved (Kercher and Nagle, 2001) and the amount of char formed (residual elements) (Lin et al., 2007). This is due to the fact that both CCA and ACQ are not organic compounds, and their precise molecular composition may vary. In addition, the thermal decomposition of all combustible materials produces a toxic smoke. Combustion toxicology indicates adverse effects produced from exposure to fire-generated toxic species (Hartzell, 1996).

In order to provide an understanding of the fundamental thermal decomposition and to analyze the evolved species and the char of wood preservatives, the examinations were divided into two categories. The first category involves the study of thermal decomposition, and examines the effectiveness of the thermal properties of 3 types of wood preservatives, creosote oil, CCA and ACQ, using thermogravimetric analysis (TGA). In the second category two kinds of spectrometric techniques are applied. One applies thermogravimetric analysis with infrared spectrometry (TGA-IR), to monitor the effectiveness, on an analytical scale, of the three preservatives and also to examine the emissions of certain compounds in each particular analysis. The other applies energy dispersive X-ray spectrometry (EDX) to examine certain residual elements of the char from each preservatives used in this study, before/after thermal decomposition. The goal of this research was to acquire fundamental knowledge of the thermal decomposition of the preservatives, while at the same time obtaining an air pollution reference for gas emissions and a disposal-end practice (of the residual elements) reference for the char.

\section{MATERIALS AND METHODS}

\section{Wood preservatives}

The commercial wood preservatives used were provided by Kunnyih Co. Ltd., Taiwan. The basic details of these preservatives are as follows:

a. Coal-tar creosote (creosote oil): type CRO33 of creosote oil (Creosote) was used, and is a black or brownish oil made by distilling coal tar that is obtained after high temperature $\left(315\right.$ to $\left.355^{\circ} \mathrm{C}\right)$ carbonization of coal, and is produced by China steel chemical Corp., Taiwan. Its solid content is about $23.72 \%$, specific gravity is $1.085\left(28.0^{\circ} \mathrm{C}\right)$.

b. Chromated copper arsenate (CCA): type 3 of CCA (CCA-3) was used, and is produced by Tanalith C Corp., England. CCA-3 oxide is light yellow in color and its concentration in an oxide-base was $2.5 \%$ containing a mixture of $28.90 \mathrm{wt} \%$ of chromium trioxide $\left(\mathrm{CrO}_{3}\right), 10.60 \mathrm{wt}$
$\%$ of cupric oxide ( $\mathrm{CuO})$, and $16.70 \mathrm{wt} \%$ of arsenic pentoxide $\left(\mathrm{As}_{2} \mathrm{O}_{5}\right)$. The concentration of CCA-3 was $3.0 \%$, and its solid content was about $2.32 \%$, specific gravity was $1.065\left(28.0^{\circ} \mathrm{C}\right)$, with a pH of 3.6.

c. Ammoniacal copper quats (ACQ): type 1 of ACQ (ACQ-1) was used, and was obtained from Koshi Corp., Japan. ACQ-1 oxide is deep green in color, and includes $\mathrm{CuO}$ with $9.00 \mathrm{wt} \%$, as well as 7.20 wt \% of N-alkyl benzyl dimethyl ammonium chloride (BKC). The concentration of ACQ-1 was 6.0\%, and its solid content was about $0.95 \%$, specific gravity was $1.008\left(27.8^{\circ} \mathrm{C}\right), \mathrm{pH}$ value was 10.3 .

\section{Thermogravimetric analysis (TGA)}

TGA is an established technique, used in the quantification of weight changes within a material, as a function of temperature or time (Hsu et al., 2000). Throughout this, TGA was carried out using a Perkin-Elmer TGA 1, fully supported by computer-controlled software options from Perkin-Elmer Thermal Analysis Systems for control and data handling. The samples, 3 types of wood preservatives after being oven dried at a temperature of $105^{\circ} \mathrm{C}$ for over $24 \mathrm{~h}$, each weighing apprpximately 5.0-10.0 mg, were placed into an open experimental sample pan and suspended from a sensitive microbalance. A furnace surrounded the sample to provide accurate heating ranging from 50 to $850^{\circ} \mathrm{C}$, while the measurements were taken. In order to isolate the decomposition step, all runs were purged in an air atmosphere, at a flow rate of $50 \mathrm{~mL} / \mathrm{min}$, with 2 kinds of heating rate, at $5^{\circ} \mathrm{C} / \mathrm{min}$ (slow-heating regime) or at $40^{\circ} \mathrm{C} / \mathrm{min}$ (fast-heating regime). That is to say, the slow-heating and fast-heating regimes were applied to compare the differences in their thermal properties and their char. The thermal decomposition for the three types of preservatives was then carried out.

\section{Thermogravimetric analysis with infrared spectrometry (TGA-IR)}

TGA, as described in previous section, is a quantitative technique that does not identify evolved compounds. To understand the evolved species produced by the thermal decomposition of the three types of wood preservatives, an analysis was carried out using a TGA (Perkin-Elmer Pyris 7 TGA model), linked to a secondary method of analysis, the Fourier-Transform Infrared Spectroscopy (using a Perkin-Elmer FTIR), which was able to identify the evolved species during the TGA measurements (Statheropoulos and kyriakou, 2000). The TGA and FTIR (TGA-IR) were connected using a transfer line with a continuous scanner in a gaseous cell. The infrared spectrometric (IR) response data was recorded by a personal computer. The spectrum time based version 2.0 software (2000, Perkin-Elmer, Inc.) obtained and analyzed the evolved species as they occurred. The samples, weighing about $5.0 \mathrm{mg}$ each, were placed in an open pan and suspended from a sensitive microbalance in the Pyris 7 TGA model. 
The conditions were set the same as for the Perkin-Elmer TGA 1, described above, regarding heating and air flow rates. The evolved species analysis was performed on the TGA-IR, and their IR spectra was then investigated by spectrum version 5.3 (2005, Perkin-Elmer, Inc.). However, the IR response obtained for various evolved species using the TGA-IR appeared about $10 \mathrm{sec}$ later, when compared to the traces of the TGA tests. To discuss the criteria and limitations of both TGA-IR and TGA for each particular analysis, and to ensure accurate results, it was necessary to carefully calculate and compare the results obtained between the decomposition temperature (obtained from the TGA) and the decomposition time of the evolved species from the IR response (obtained from the TGA-IR).

\section{Energy Dispersive X-ray Spectrometer (EDX)}

TGA-IR, described in the previous section, is a technique to investigate the evolved species by thermal decomposition, but it does not identify the char after combustion. To understand the char of the preservatives, the scanning electron microscope combined with the energy dispersive X-ray spectrometer (SEM-EDX) was employed. It can be applied directly to a material, to determine the amount of all the elements in a single image analysis. It is a powerful tool for studying the mineral distribution and more precisely the effect of the elements on this distribution (Kotz et al., 1990). In these experiments, to simulate the char obtained from the end of the TGA tests, all preservative samples were each placed into an individual crucible and then burned using a burner (DF-303, Deng Yng Co. Ltd.). The temperature was managed the same as for the TGA test, from room temperature to $850^{\circ} \mathrm{C}$, but with a heating rate of $20^{\circ} \mathrm{C} / \mathrm{min}$ (Lin et al., 2006). The residual char was analyzed using a SEM-EDX (E HONG Instrument Co. Ltd., a Hitachi general agent in Taiwan, from Hitachi High-Technologies Corporation, Japan). SEM pictures were taken using a Hitachi S-3400N scanning electron microscope. For all investigations in this study the beam energy was $10 \mathrm{~nm}$ at $15.0 \mathrm{kV}$ with a distance of $10.0 \mathrm{~mm}$ to the preservatives samples, in order to obtain the excitation of all the elements. Analysis of the elements was carried out by EDX analysis using a Horiba EDX $7021 \mathrm{H}$ system. To determine their distribution, a smart Map acquisition was used, which is capable of the simultaneous acquisition of the X-ray data from each pixel on the image area with $2.00 \mathrm{kSE}$ of magnification. The results of the residual elements in the char were analyzed for all samples.

\section{RESULTS AND DISCUSSION}

\section{Thermal decomposition of wood preservatives}

Thermogravimetric analysis (TGA) is a common technique for measuring the weight change of a material as a function of temperature. To comprehend the thermal properties (thermal decomposition, decomposition step, and char) of the three types of preservatives, the preservatives samples were measured by TGA, after having been oven-dried. Decomposition profiles were obtained while the samples were being heated at a rate of 5 or $40^{\circ} \mathrm{C} / \mathrm{min}$ in air, between $50^{\circ} \mathrm{C}$ (initial temperature) and $850^{\circ} \mathrm{C}$ (end temperature). The relationships of the TGA and the DTG curves between temperature and weight loss, and the derivative weight for each preservatives sample, Creosote, CCA-3 and ACQ-1, are shown in Fig. 1.
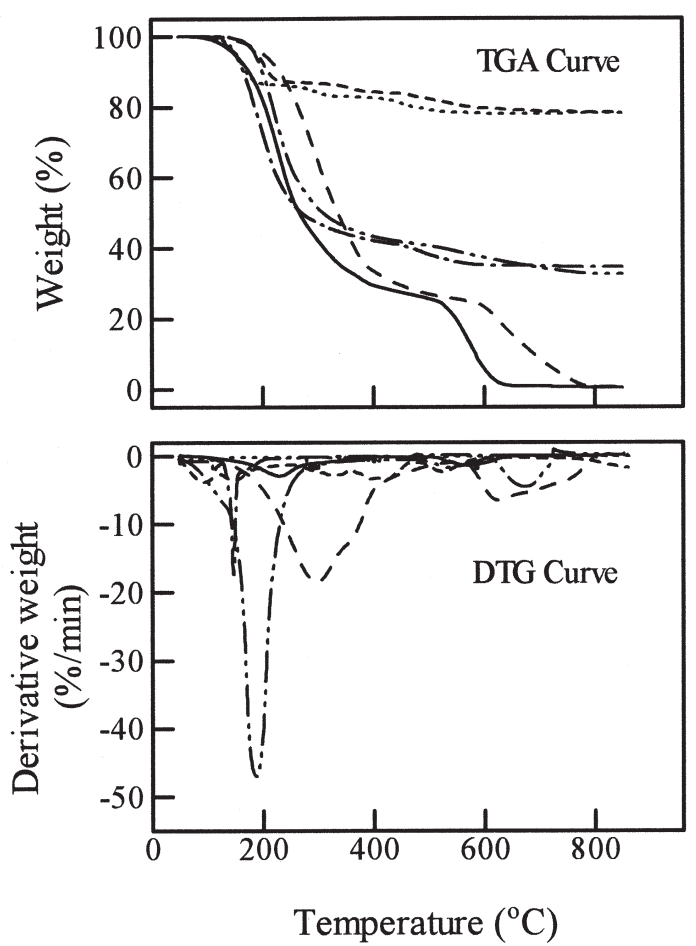

Fig. 1. TGA and DTG curves for 3 types of wood preservatives (Creosote, CCA-3, and ACQ-1) in air at 5 or $40^{\circ} \mathrm{C} / \mathrm{min}$.

Symbols: — : Creosote $\left(5^{\circ} \mathrm{C}\right) ;----$ : Creosote $\left(40^{\circ} \mathrm{C}\right)$; ---- : CCA-3 $\left(5^{\circ} \mathrm{C}\right) ; \quad----\quad: \mathrm{CCA}-3\left(40^{\circ} \mathrm{C}\right)$; - - : ACQ-1 $\left(5^{\circ} \mathrm{C}\right) ; \quad--$ : ACQ-1 $\left(40^{\circ} \mathrm{C}\right)$.

Notes: CCA-3: The type 3 of chromated copper arsenate; ACQ-1: The type 1 of ammoniacal copper quats; Creosote: the type CRO33 of creosote oil (creosote oil-CRO33).

$5{ }^{\circ} \mathrm{C}$ : $5^{\circ} \mathrm{C} / \mathrm{min}$ of heating rate; $40^{\circ} \mathrm{C}$ : $40^{\circ} \mathrm{C} / \mathrm{min}$ of heating rate.

Regardless of the heating rate, the three types of wood preservatives typically showed gradual weight loss. The thermogram, resulting from the analysis of Creosote at $5^{\circ} \mathrm{C} / \mathrm{min}$ (solid line) or $40^{\circ} \mathrm{C} / \mathrm{min}$ (dash line) heating rate, showed that at temperatures of 50 to about $600^{\circ} \mathrm{C}$ there were three subtle changes (shoulders) for the solid line and two shoulders for the dash line, suggesting that the thermal decomposition of Creosote was influenced by the slow-heating regime and by the fast-heating regime in an air atmosphere. The onset of weight loss under air was observed at temperatures of $179.20,400.42$ and $547.63^{\circ} \mathrm{C}$ for heating at a rate of $5{ }^{\circ} \mathrm{C} / \mathrm{min}$, as well as at temperatures of 228.54 and $599.77^{\circ} \mathrm{C}$ for a heating rate of $40^{\circ} \mathrm{C} / \mathrm{min}$. This is supported by the derivative (DTG) curve, which shows three peaks at temperatures of $230.78,371.48$ and $586.77^{\circ} \mathrm{C}$ for a heating rate of $5^{\circ} \mathrm{C} / \mathrm{min}$, and at tempera- 
tures of 295.26 and $622.89^{\circ} \mathrm{C}$ for a heating rate of $40^{\circ} \mathrm{C} / \mathrm{min}$, (the bottom of Fig. 1). The amount of char for both heating rates, at a temperature of $850{ }^{\circ} \mathrm{C}$, $5^{\circ} \mathrm{C} / \mathrm{min}$ was $0.50 \mathrm{wt} \%$ and for $40^{\circ} \mathrm{C} / \mathrm{min}$ it was $0.63 \mathrm{wt}$ $\%$. Regardless of the heating rate, these decomposition temperatures of Creosote were all lower than for CCA-3 and ACQ-1.

To elucidate the comprehension of the thermal properties of CCA-3 and ACQ-1 because they both are water-based preservatives, a comparison is made between the slow-heating regime and the fast-heating regime in air atmosphere for both preservatives. The results are also shown in Fig. 1. Regardless of the heating rate, the CCA-3 weight loss at a heating rate of either $5^{\circ} \mathrm{C} / \mathrm{min}$ (dot line) or $40^{\circ} \mathrm{C} / \mathrm{min}$ (short dash line) is significantly less than that of ACQ-1 at a heating rate of $5^{\circ} \mathrm{C} / \mathrm{min}$ (dash dot dash line) or $40^{\circ} \mathrm{C} / \mathrm{min}$ (dash dot dot dash line). The results of $\mathrm{CCA}-3$ show that the weight loss gradually decreases. The onset of weight loss for the $40{ }^{\circ} \mathrm{C} / \mathrm{min}$ heating rate was observed at temperatures of $176.27,330.96,460.39$ and $512.26^{\circ} \mathrm{C}$. For the heating rate of $5^{\circ} \mathrm{C} / \mathrm{min}$ the weight loss was evident at temperatures of $138.84,273.08,420.36$ and $431.08^{\circ} \mathrm{C}$. These findings are supported by the derivative (DTG) curve, and agree with those in the literature (Helsen and Bulck, 1998; Kercher and Nagle, 2001; Lee et al., 2005; Lin et al., 2006). For the amount of char, at a tempera- ture of $850^{\circ} \mathrm{C}$, for CCA-3 it was 78.06 wt \% at a heating rate of $5{ }^{\circ} \mathrm{C} / \mathrm{min}$ and $78.73 \mathrm{wt} \%$ at a heating rate of $40^{\circ} \mathrm{C} / \mathrm{min}$. These numbers are higher than the ACQ-1 at heating rates of either 5 or $40^{\circ} \mathrm{C} / \mathrm{min}$. Hirata et al. (1993) reported that $\mathrm{Cr}$ (chromium) and $\mathrm{Cu}$ (copper) from the CCA preservatives were largely present in the char and that As (arsenic) was easily volatilized with the increase in temperature during combustion. Some researches (Kercher and Nagle, 2001; Cooper et al., 2003; Helsen and Bulck, 2005) stated that in the TGA tests, when CCA preservatives were analyzed with air, $\mathrm{AS}_{2} \mathrm{O}_{5}$ was formed in a gaseous state and that it disappeared at a temperature of over $600^{\circ} \mathrm{C}$. In addition, $\mathrm{CuO}$ produced $\mathrm{Cu}_{2} \mathrm{O}$ when the temperature reached about $800{ }^{\circ} \mathrm{C}$ both in air atmosphere, CO was then further volatilized and only $\mathrm{Cu}$ remained. Also, Cr (III) is a stable element with an unproductive thermal decomposition (Lin et al., 2006). In other words, it is evident that after combustion the $\mathrm{Cr}$ and $\mathrm{Cu}$ from the preservatives (CCA-3) are remained.

The results of ACQ-1 show that the weight loss drastically decreases in air at either heating rate. The composition temperature for the heating rate of $5^{\circ} \mathrm{C} / \mathrm{min}$ was lower than that of $40^{\circ} \mathrm{C} / \mathrm{min}$. The onset of weight loss for the $5^{\circ} \mathrm{C} / \mathrm{min}$ heating rate under air was observed at temperatures of 156.49 , and $464.40^{\circ} \mathrm{C}$. At a $40^{\circ} \mathrm{C} / \mathrm{min}$ heating rate under air, the onset of weight loss was

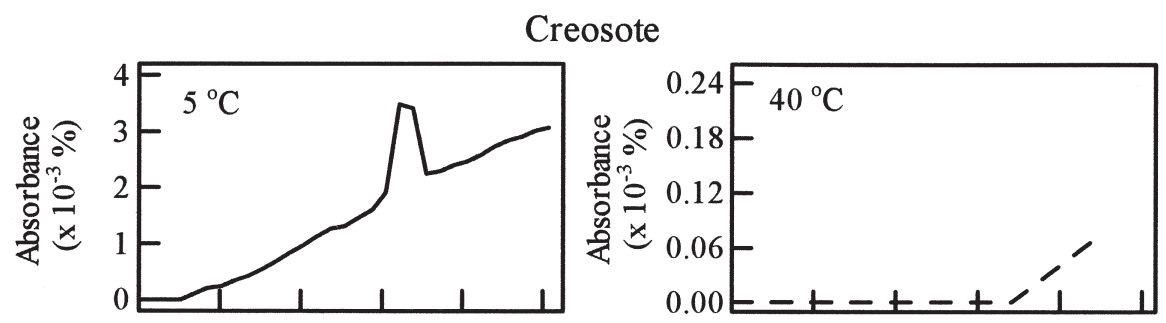

CCA-3
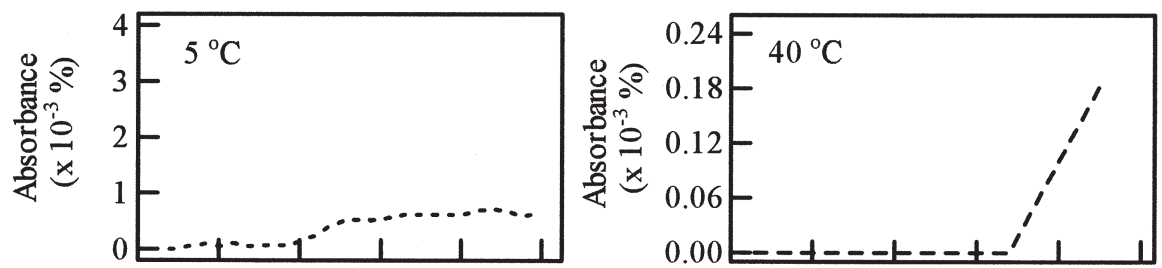

ACQ-1
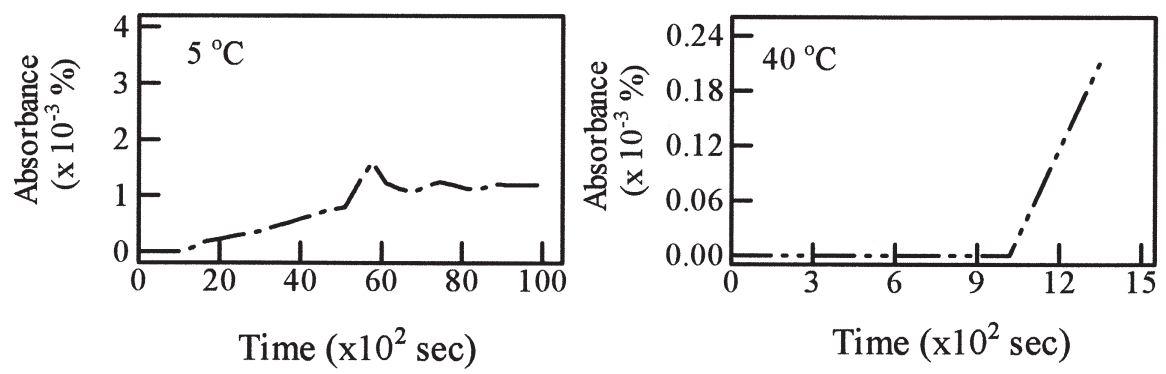

Fig. 2. IR response of 3 types of wood preservatives (Creosote, CCA-3, and ACQ-1) in air at 5 or $40^{\circ} \mathrm{C} / \mathrm{min}$ from TGA-IR analysis.

Symbols: The symbols are the same as Figure 1.

Note: $\quad$ Abbreviations of Creosote, CCA-3, ACQ-1 and $5{ }^{\circ} \mathrm{C}, 40^{\circ} \mathrm{C}$ are the same as Figure 1 . 
obtained at temperatures of 187.00 and $515.95{ }^{\circ} \mathrm{C}$. These findings are also supported by the derivative (DTG) curve. For the amount of char in this portion of the TGA tests, ACQ-1 was 34.59 wt $\%$ at $5{ }^{\circ} \mathrm{C} / \mathrm{min}$ heating rate and $32.62 \mathrm{wt} \%$ at $40^{\circ} \mathrm{C} / \mathrm{min}$ heating rate. These results were the same as reported previously (Lin et al., 2006). ACQ preservatives, a combination of copper and organic biocides, indicated that the main residual element was $\mathrm{Cu}$ (Lin et al., 2007), that is, the other elements were volatilized with the increase in temperature during combustion, such as BKC, one of the main compounds used in this study for ACQ-1. Therefore, the char of CCA-3 was higher than that of ACQ-1 (the top of Fig. 1), based on the different heating rates (5 or $40^{\circ} \mathrm{C} / \mathrm{min}$ ) set in this study.

\section{Infrared spectrometric response of wood preserv- atives}

Figure 2 shows the infrared spectrometric (IR) response of the three types of preservatives for both heating rates, at $5{ }^{\circ} \mathrm{C} / \mathrm{min}$ (the left side of Fig. 2) and $40^{\circ} \mathrm{C} / \mathrm{min}$ (the right side of Fig. 2) in the TGA-IR measurements. The change in absorbance (concentration of evolved species, \%) corresponds to the increase in decomposition time for the three preservatives. The concentration of evolved species for the IR response of Creosote with a slow-heating regime, $5^{\circ} \mathrm{C} / \mathrm{min}$, increased slowly to about $1019.75 \sec \left(134.15^{\circ} \mathrm{C}\right)$ from the start of decomposition. Subsequently, this increasing tendency rose linearly to about $6095.85 \mathrm{sec}$ $\left(557.15^{\circ} \mathrm{C}\right)$. The high point of absorbance was 6433.37 $\sec \left(585.28^{\circ} \mathrm{C}\right)$. After that, the change in concentrations of evolved species decreased to about $7108.85 \mathrm{sec}$ $\left(641.57^{\circ} \mathrm{C}\right)$ and then tended to increase until the end of decomposition. Furthermore, the IR response of Creosote at a $5^{\circ} \mathrm{C} / \mathrm{min}$ heating rate, between 6433.37 and $6771.06 \mathrm{sec}\left(613.42^{\circ} \mathrm{C}\right)$, showed a greater mountain peak.

The concentration of evolved species from the IR response of CCA-3 at a $5{ }^{\circ} \mathrm{C} / \mathrm{min}$ heating rate took the shape of a plateau. The high point of absorbance occurred at $8791.23\left(781.77^{\circ} \mathrm{C}\right)$. For ACQ-1 the concentration of evolved species in the IR response increased slowly to about $5088.32 \mathrm{sec}\left(473.19^{\circ} \mathrm{C}\right)$ from the beginning of decomposition. Subsequently, the time change in the concentration of evolved species became like the ridge of a house in which the increasing tendency rose linearly to a sharp peak of about 5763.73 $\left(529.48^{\circ} \mathrm{C}\right)$. After that, the change in concentrations of evolved species decreased to about $6782.00 \mathrm{sec}$ $\left(614.33^{\circ} \mathrm{C}\right)$ and then increased slowly until the end of decomposition. This suggests that at a heating rate of $5{ }^{\circ} \mathrm{C} / \mathrm{min}$, the concentration of evolved species for ACQ-1 is higher than that for CCA-3.

Comparing the IR response of all preservatives at a heating rate of $5{ }^{\circ} \mathrm{C} / \mathrm{min}$, the absorbance levels for Creosote were higher than for CCA-3 and ACQ-1. This indicated that the concentration of evolved species of water-based preservatives was less than those of oil-based ones. Of them all, CCA-3 was inferred to be the best preservatives with the least environmental impact in this study, if the disposal process of the preservatives was combustion and considering the results of air pollution only. A similar conclusion was reached in a previous research (Lin et al., 2007), which indicated that CCA-3 was the better environmentally friendly preservatives for wood protection, because the emission contents (such as carbon monoxide, nitrogen monoxide and sulfur dioxide) of CCA-3 were less than those of ACQ-1, considering their environmental impact only during combustion.

The right side of Fig. 2 also shows the IR response of the three types of wood preservatives with a heating rate of $40^{\circ} \mathrm{C} / \mathrm{min}$ in the TGA-IR measurements. The change in concentration of evolved species corresponds to the increase in decomposition time for the three preservatives. The concentration increased slowly, about 1018.54 to $1024.46 \mathrm{sec}\left(722.36\right.$ to $\left.726.31^{\circ} \mathrm{C}\right)$, from the start of decomposition. Subsequently, the increasing tendency rose linearly to the end of decomposition. The IR response of ACQ-1 showed a greater peak at the end than that of Creosote and CCA-3. This suggests that at $40^{\circ} \mathrm{C} / \mathrm{min}$ of the heating rate, the concentration of evolved species for ACQ-1 is higher than that for either Creosote or CCA-1. Comparing the IR response of all preservatives at both heating rates, the absorbance levels at $5^{\circ} \mathrm{C} / \mathrm{min}$ for oil-based preservatives were higher than for water-based one, but at $40^{\circ} \mathrm{C} / \mathrm{min}$ the results were reversed. This indicates that for wood preservatives the concentration of evolved species is related to the heating rate, because of the variation in decomposition steps.

\section{TGA-IR spectra and typical structure of wood preservatives}

At present much attention is being given to the use of wood preservatives, because of the fact that during combustion they emit toxic gases and produce a corrosive smoke. Exposure to these toxic emissions is harmful to humans and in addition can cause damage to expensive equipment (Ladomersky, 2000; Lin et al., 2007). With the use of TGA-IR, it is possible to simultaneously monitor evolved species, decomposition temperature and the concentrations formed (absorbance), as well as the evolution profile of certain compounds. Moreover, IR spectrometry is a common means of evaluating a functional base when a material undergoes degradation. Lin et al. (2004) reported that the use of TGA-IR in combination with TGA analysis for analyzing the thermal behavior of 4 types of adhesives led to useful results, involving the identification of pyrolysis products.

The evolution of decomposition time (or temperature) on absorbance and wavenumbers (basically, IR spectra) for three types of preservatives samples (Creosote, CCA-3 and ACQ-1 after oven-dried) is shown in Fig. 3. The distribution of wavenumbers at the end of each $600 \mathrm{sec}$ for the heating rate of $5^{\circ} \mathrm{C} / \mathrm{min}$ (the left side of Fig. 3) and at the end of each $100 \mathrm{sec}$ for a heating rate of $40^{\circ} \mathrm{C} / \mathrm{min}$ (the right side of Fig. 3), during 

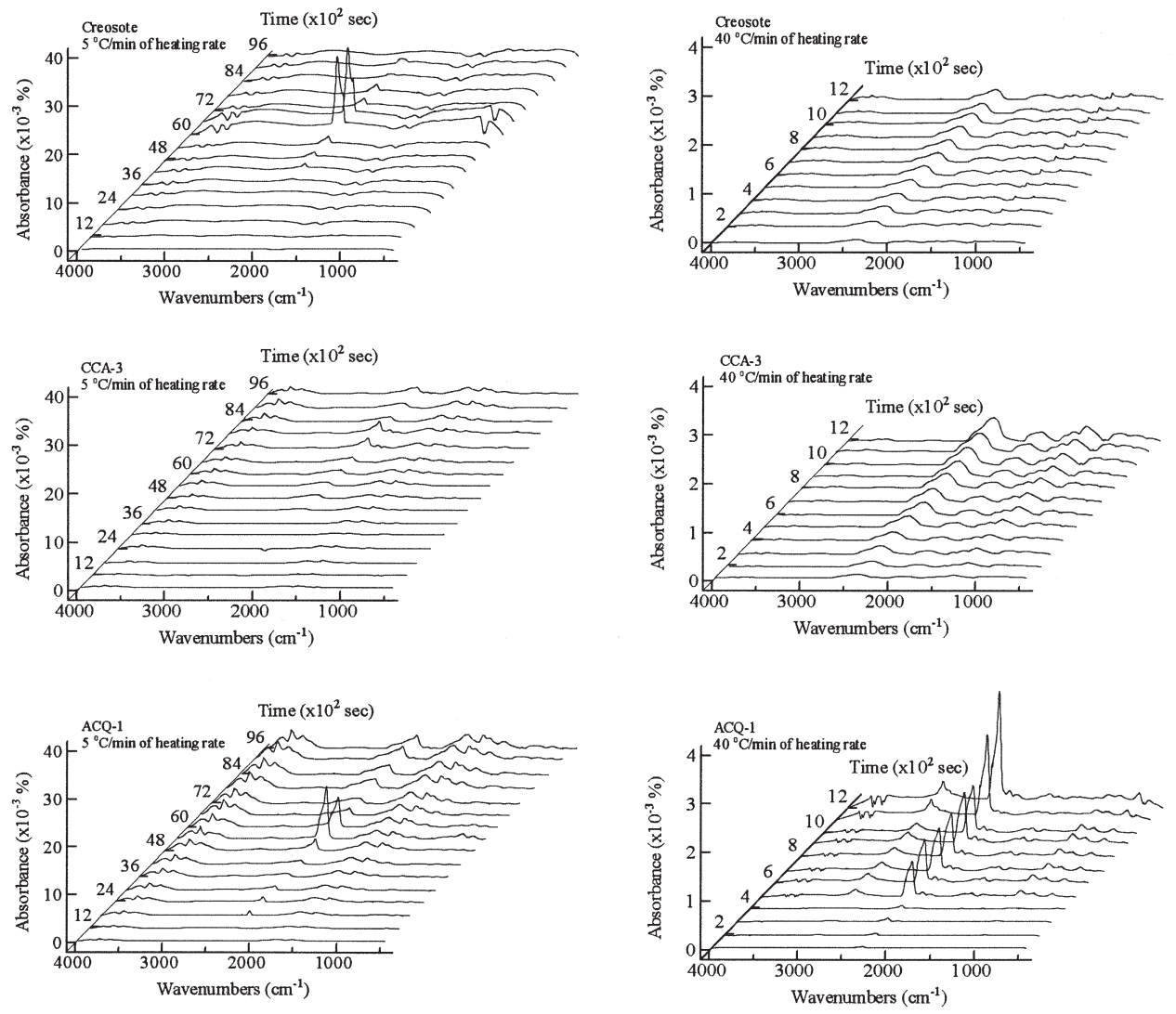

Fig. 3. TGA-IR spectra of 3 types of wood preservatives in air with 5 or $40^{\circ} \mathrm{C} / \mathrm{min}$ (Creosote, CCA-3, and ACQ-1).

Note: Abbreviations of Creosote, CCA-3 and ACQ-1 are the same as Figure 1.

decomposition, was analyzed. The results are summarized below, it analyzes the data between the TGA curve (decomposition temperature) in the TGA tests and the TGA-IR response (decomposition time along with wavenumbers and absorbance) in the TGA-IR measurement.

For the TGA-IR spectra of Creosote at a heating rate of $5{ }^{\circ} \mathrm{C} / \mathrm{min}$ ( top left in Fig. 3 ) and at a heating rate of $40^{\circ} \mathrm{C} / \mathrm{min}$ (top right in Fig. 3), the carbon dioxide $\left(\mathrm{CO}_{2}\right)$ peak, located at 2296 and $2356 \mathrm{~cm}^{-1}$, started showing from about $3600 \mathrm{sec}$ (at a temperature of about $349^{\circ} \mathrm{C}$ in the TGA tests) to the end for a heating rate of $5{ }^{\circ} \mathrm{C} / \mathrm{min}$ and was steady from beginning to the end for a heating rate of $40^{\circ} \mathrm{C} / \mathrm{min}$. The $\mathrm{CO}_{2}$ increased linearly to maximum absorbance at about $6000 \mathrm{sec}\left(549^{\circ} \mathrm{C}\right)$, then decreased at about $6780 \mathrm{sec}\left(614^{\circ} \mathrm{C}\right)$ and decreased lineally the concentration of $\mathrm{CO}_{2}$ till the end of the tests for the heating rate of $5^{\circ} \mathrm{C} / \mathrm{min}$. The other $\mathrm{CO}_{2}$ peak was located at $617 \mathrm{~cm}^{-1}$ for the heating rate of $5^{\circ} \mathrm{C} / \mathrm{min}$, and was from about $2400 \mathrm{sec}\left(249^{\circ} \mathrm{C}\right)$ to the end, but at $666 \mathrm{~cm}^{-1}$ for a heating rate of $40^{\circ} \mathrm{C} / \mathrm{min}$ the other $\mathrm{CO}_{2}$ peak was from about $400 \mathrm{sec}\left(82.5^{\circ} \mathrm{C}\right)$ to the end. In addition, the peaks at 1585 and $3780 \mathrm{~cm}^{-1}$ were due to the $\mathrm{N}-\mathrm{H}$ stretching of $\mathrm{NH}_{2}$ moieties (Zhu and Shi, 2001) from about $1200 \mathrm{sec}\left(149^{\circ} \mathrm{C}\right)$ to the end for the heating rate of $5^{\circ} \mathrm{C} / \mathrm{min}$. A higher concentration of $\mathrm{N}-\mathrm{H}$ stretching was seen between 6000 and $6600 \mathrm{sec}\left(549\right.$ to $\left.599^{\circ} \mathrm{C}\right)$. For the heating rate of $5^{\circ} \mathrm{C} / \mathrm{min}$ the range from 5400 to
$9000 \mathrm{sec}\left(499\right.$ to $\left.799^{\circ} \mathrm{C}\right)$ showed a slight peak at $718 \mathrm{~cm}^{-1}$, which was attributed to the groups of $-\mathrm{CH}_{2}-$ rocking and another slight peak, at $3670 \mathrm{~cm}^{-1}$, was attributed to the $\mathrm{OH}$ group, from about $1800 \mathrm{sec}\left(199^{\circ} \mathrm{C}\right)$ to the end. However, for the heating rate of $40^{\circ} \mathrm{C} / \mathrm{min}$, some of the weak peaks, at 3741, 1794, 1316 and $814 \mathrm{~cm}^{-1}$, were due to the $\mathrm{OH}$ group, $\mathrm{C}=\mathrm{O}$ (carbonyl group) stretching, the group of $\mathrm{C}-\mathrm{NO}_{2}$ stretching and $\mathrm{N}-\mathrm{H}$ deformation vibration of $\mathrm{NH}_{2}$ moieties, all ranging from the beginning of the combustion to the end. These results indicate that from the TGA-IR response the evolved species for the slow-heating regime $\left(5^{\circ} \mathrm{C} / \mathrm{min}\right)$ were less than those for the fast-heating regime $\left(40^{\circ} \mathrm{C} / \mathrm{min}\right)$.

The TGA-IR spectra of CCA-3 are shown in Fig. 3. The spectra on the centre left in Fig. 3 is for the heating rate of $5^{\circ} \mathrm{C} / \mathrm{min}$ and the one on the centre right is for the heating rate of $40^{\circ} \mathrm{C} / \mathrm{min}$. These results indicate that the fast-heating regime presented many more evolved species. The absorbance peaks and the time location (including the decomposition temperature) of $\mathrm{CO}_{2}$ at 2296 and $2356 \mathrm{~cm}^{-1}$ were from about $2400 \mathrm{sec}\left(249^{\circ} \mathrm{C}\right)$ to the end for the heating rate of $5^{\circ} \mathrm{C} / \mathrm{min}$, but from the beginning to the end for the heating rate of $40^{\circ} \mathrm{C} / \mathrm{min}$. $\mathrm{C}=\mathrm{O}$ stretching at $1725 \mathrm{~cm}^{-1}$ was from about $1200 \mathrm{sec}$ $\left(149^{\circ} \mathrm{C}\right)$ to the end for the heating rate at $5^{\circ} \mathrm{C} / \mathrm{min}$ and from the beginning to the end for the heating rate of $40^{\circ} \mathrm{C} / \mathrm{min}$. One of the lower peaks was from the begin- 
ning to the end for the heating rate of $5^{\circ} \mathrm{C} / \mathrm{min}$ and from about $200 \mathrm{sec}\left(176^{\circ} \mathrm{C}\right)$ to the end for the heating rate of $40^{\circ} \mathrm{C} / \mathrm{min}$. This is attributed to $\mathrm{N}-\mathrm{H}$ stretching at $3780 \mathrm{~cm}^{-1}$. Other low peaks for the groups of $-\mathrm{CH}_{2}-$ rocking at 710 to $718 \mathrm{~cm}^{-1}$ from the beginning to the end showed up in the slow and faster-heating regimes. Except those evolved species, several weak peaks, for the heating at a rate of $40^{\circ} \mathrm{C} / \mathrm{min}$ only, at 1805,1437 , 1300, 932 and $817 \mathrm{~cm}^{-1}$ emerged due to $=\mathrm{CH}_{2}, \mathrm{OH}$ groups, $\mathrm{C}-\mathrm{NO}_{2}$ stretching, $-\mathrm{OH}$ out-of plane wagging, $-\mathrm{NH}_{2}$ moieties etc., during the period of the TGA-IR tests. These results of CCA-3 indicated that there were more evolved species for the heating rate of $40^{\circ} \mathrm{C} / \mathrm{min}$ than those for the heating rate of $5^{\circ} \mathrm{C} / \mathrm{min}$.

For the TGA-IR spectra of ACQ-1 at the heating rate of $5^{\circ} \mathrm{C} / \mathrm{min}$ (bottom left in Fig. 3), the peaks of $\mathrm{CO}_{2}$ were located at 2296 and $2356 \mathrm{~cm}^{-1}$ and began from about $1800 \mathrm{sec}\left(199^{\circ} \mathrm{C}\right)$ to the end of the tests, and the highest absorbance showed at $5400 \mathrm{sec}\left(499^{\circ} \mathrm{C}\right)$. The other $\mathrm{CO}_{2}$ weak peak, located at $666 \mathrm{~cm}^{-1}$, was from about $2400 \mathrm{sec}\left(249^{\circ} \mathrm{C}\right)$ to the end and a higher concentration of $\mathrm{CO}_{2}$ was also seen at that point (5400 sec.). Another wavenumber at $3747 \mathrm{~cm}^{-1}$ was assigned to the $\mathrm{N}-\mathrm{H}$ stretching of $\mathrm{NH}_{2}$ moieties (Zhu and Shi, 2001) from about the beginning to the end and the highest point was located at the end. For the heating rate of $40^{\circ} \mathrm{C} / \mathrm{min}$ (bottom right in Fig. 3), the $\mathrm{CO}_{2}$ peak was located at 2296 and $2356 \mathrm{~cm}^{-1}$ from the beginning to about $1210 \mathrm{sec}\left(850^{\circ} \mathrm{C}\right)$. The concentration of $\mathrm{CO}_{2}$ increased linearly from about $400 \mathrm{sec}\left(310^{\circ} \mathrm{C}\right)$ till the

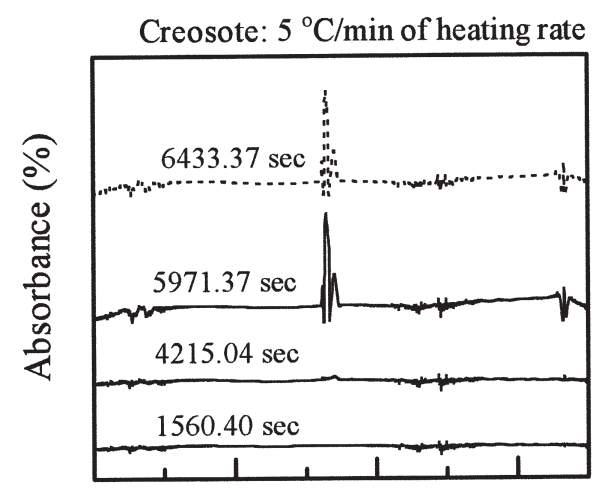

Creosote: $40{ }^{\circ} \mathrm{C} / \mathrm{min}$ of heating rate
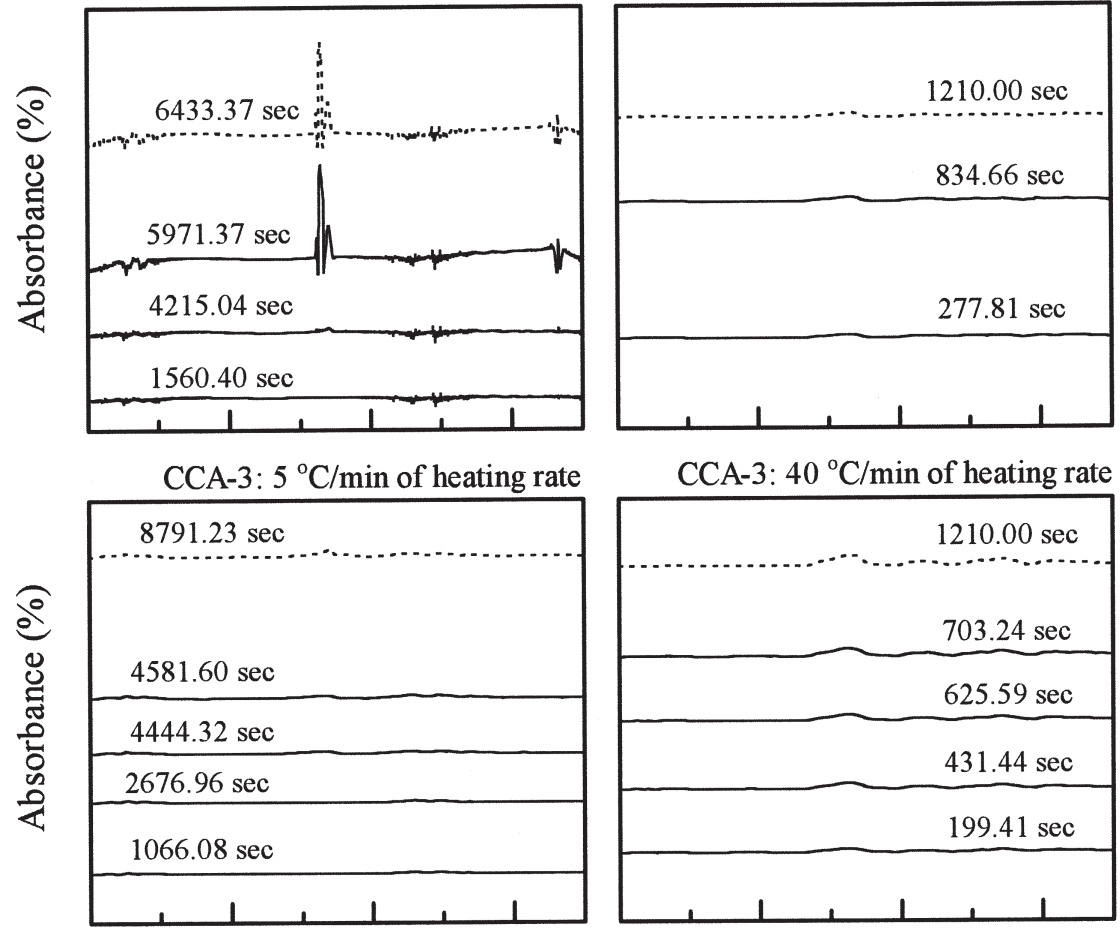

CCA-3: $40^{\circ} \mathrm{C} / \mathrm{min}$ of heating rate
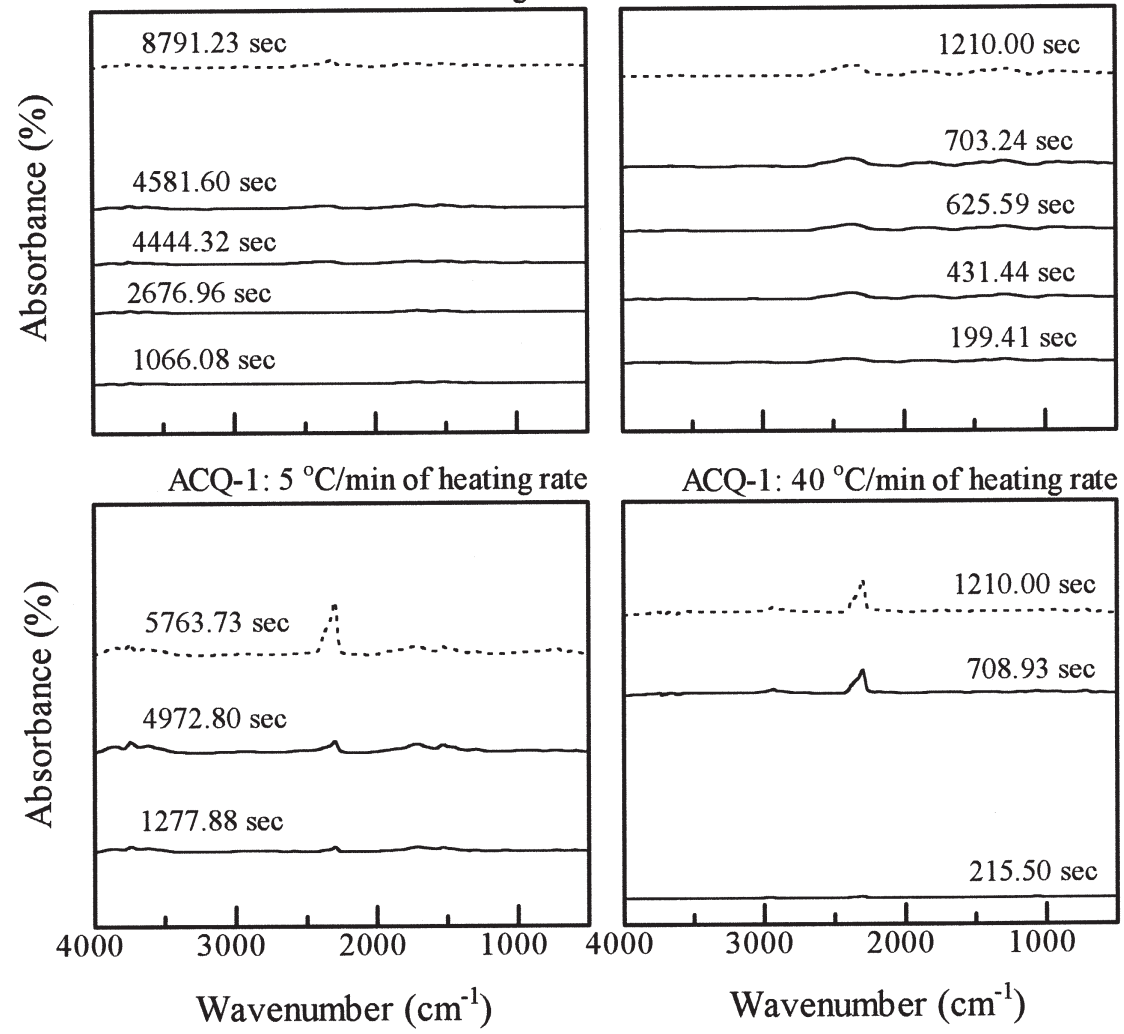

Fig. 4. IR spectra of 3 types of wood preservatives (Creosote, CCA-3 and ACQ-1) at the maximum value of absorbance from IR response and at the decomposition steps of each specimen.

Symbols:- - - : : Maximum value, $\longrightarrow$ : decomposition step.

Note: Abbreviations of Creosote, CCA-3 and ACQ-1 are the same as Figure 1. 
Table 1. EDX analysis for 3 types of wood preservatives before and after the combustion

Unit: weight (\%)

\begin{tabular}{|c|c|c|c|c|c|c|c|}
\hline \multirow{2}{*}{ Element } & \multirow{2}{*}{ Orbital } & \multicolumn{2}{|c|}{ Creosote } & \multicolumn{2}{|c|}{ CCA-3 ${ }^{1)}$} & \multicolumn{2}{|c|}{ ACQ-1 ${ }^{1)}$} \\
\hline & & before & after & before & after & before & after \\
\hline $\mathrm{C}$ & \multirow{11}{*}{ K } & 88.58 & 82.75 & 4.30 & 2.70 & 3.74 & 22.13 \\
\hline $\mathrm{O}$ & & 7.77 & 14.64 & 59.78 & 33.50 & 29.94 & 26.38 \\
\hline $\mathrm{Al}$ & & - & - & - & - & - & - \\
\hline $\mathrm{Mg}$ & & - & - & - & - & - & 0.36 \\
\hline $\mathrm{Na}$ & & - & 0.55 & - & - & - & - \\
\hline $\mathrm{S}$ & & 3.65 & 2.06 & 1.39 & 0.86 & - & 0.66 \\
\hline $\mathrm{P}$ & & - & - & - & - & - & - \\
\hline $\mathrm{K}$ & & - & - & - & - & - & 0.33 \\
\hline $\mathrm{Cl}$ & & - & - & - & - & 0.55 & - \\
\hline $\mathrm{Ca}$ & & - & - & - & - & - & - \\
\hline $\mathrm{Cr}$ & & - & - & 7.41 & 34.99 & - & - \\
\hline $\mathrm{Cu}$ & \multirow[b]{2}{*}{$\mathrm{L}$} & - & - & 16.29 & 16.69 & 65.76 & 50.14 \\
\hline As & & - & - & 10.21 & 11.89 & - & - \\
\hline
\end{tabular}

${ }^{1)}$ Abbreviations of CCA-3 and ACQ-1 are the same as Figure 1.

end of the tests and the highest level of absorbance was at the end of the tests. The range from about $400 \mathrm{sec}$ $\left(310^{\circ} \mathrm{C}\right)$ to the end showed two weak peaks of absorbance at $3609 \mathrm{~cm}^{-1}$ and $3747 \mathrm{~cm}^{-1}$, which were attributed to the $\mathrm{N}-\mathrm{H}$ stretching of $\mathrm{NH}_{2}$ moieties and the $\mathrm{OH}$ groups. In addition, several weak peaks, for the heating at a rate of $40^{\circ} \mathrm{C} / \mathrm{min}$ only, at $1731,1385,1273$, 1075,930 , and $716 \mathrm{~cm}^{-1}$ were due to $\mathrm{C}=\mathrm{O}$ stretching, $-\mathrm{CH}_{3}, \mathrm{~N}-\mathrm{NO}_{2}, \mathrm{C}-\mathrm{O}$ and $-\mathrm{OH}$ out-of plane wagging, and groups of $-\mathrm{CH}_{2}-$ rocking etc. from about $400 \mathrm{sec}$ $\left(310^{\circ} \mathrm{C}\right)$ to the end, during the period of the TGA-IR tests. These results were also the same as CCA-3, indicating evolved species for the heating rate of $5^{\circ} \mathrm{C} / \mathrm{min}$ were less than those for the heating rate of $40^{\circ} \mathrm{C} / \mathrm{min}$.

\section{Relationship of thermal decomposition and IR response of wood preservatives}

Considering the sharp increase (decomposition step) of weight loss in the TGA tests and the IR response from the TGA-IR analysis, the relationships for all preservatives used in this study are shown in Fig. 4.

The maximum value (dot line) of the three types of preservatives from the IR response in the TGA-IR tests, and the decomposition step (solid line) in accordance with the decomposition time in the TGA tests, found that all preservatives did not show a lot of evolved species during the initial decomposition step: Creosote at $1560.40 \mathrm{sec}\left(179.20^{\circ} \mathrm{C}\right), \mathrm{CCA}-3$ at $1066.08 \mathrm{sec}$ $\left(138.84^{\circ} \mathrm{C}\right)$ and $\mathrm{ACQ}-1$ at $1277.88 \mathrm{sec}\left(156.49^{\circ} \mathrm{C}\right)$ for a heating rate of $5^{\circ} \mathrm{C} / \mathrm{min}$ and Creosote at $277.81 \mathrm{sec}$ $\left(228.54^{\circ} \mathrm{C}\right), \mathrm{CCA}-3$ at $199.41 \mathrm{sec}\left(176.27^{\circ} \mathrm{C}\right)$ and ACQ-1 at $215.50 \mathrm{sec}\left(187.00^{\circ} \mathrm{C}\right)$ for a heating rate of $40^{\circ} \mathrm{C} / \mathrm{min}$. Nevertheless, they all showed a significantly higher amount (concentration) of $\mathrm{CO}_{2}$ emitted at the top point (dot line) during absorbance between 2296 and $2356 \mathrm{~cm}^{-1}$, particularly for Creosote with a heating rate of $5{ }^{\circ} \mathrm{C} / \mathrm{min}$ at either $5971.37\left(547.63^{\circ} \mathrm{C}\right.$; the third decomposition step) or at $6433.37\left(585.28^{\circ} \mathrm{C}\right.$; the top point of absorbance) and CCA-3 with a heating rate of $5^{\circ} \mathrm{C} / \mathrm{min}$ at $5763.73\left(479.01^{\circ} \mathrm{C}\right.$; the top point of absorbance), as well as ACQ-1 with a heating rate of $40^{\circ} \mathrm{C} / \mathrm{min}$ at either $708.93\left(515.95^{\circ} \mathrm{C}\right.$; the second decomposition step) or at $1210\left(850.00^{\circ} \mathrm{C}\right.$; the end of the tests). In combustion toxicology, $\mathrm{CO}_{2}$ is normally considered to be a significant toxicant and is also the best-known greenhouse gas, capable of increasing the average global temperature (Allaby, 2000; Aplin et al., 2000). The results (Fig. 5) also showed that at either the slow or the fast-heating regime both Creosote and ACQ-1 produced more types and higher concentrations of evolved species than CCA-3.

\section{EDX analysis of wood preservatives}

Because the chemical ingredients of both CCA-3 and ACQ-1 are composed of salts, and Creosote is obtained from coal tar at a higher temperature through distillation, the residual elements will remain in the char after thermal decomposition (Lin et al., 2006). In general the residual char is processed by landfilling it. (Jang, 1997). The residual elements in char, therefore, need to be investigated to determine what the char contents of these three types of preservative are. In this portion of the experiment, in order to analyze the char of these three preservatives in the end of the TGA tests, all samples were individually burned using a burner to simulate the char obtained from the end of the TGA tests, and then were carried out by using EDX. The results are shown in Table 1.

The main element of the oil-based preservatives used in this study, was C (carbon), 88.58\% before combustion and $82.75 \%$ after combustion. For the water-based preservatives, CCA-3 was $4.30 \%$, and ACQ-1 was 3.74\%. After combustion, the relative proportion of $\mathrm{C}$ was $2.70 \%$ for CCA-3 and $22.13 \%$ for the ACQ-1. The results for element O (oxygen) showed that Creosote had a relative twofold increase, $7.77 \%$ before being burned, 14.64\% after being burned. For water-based preservatives this was relatively decreased, 59.78 to $33.50 \%$ for CCA-3 and 29.94 to $26.38 \%$ for ACQ-1. The results also showed that the amount of $\mathrm{S}$ 
(sulfur) for Creosote was 3.65\% before combustion, and $2.06 \%$ after being burned. For two water-based preservatives, the results showed that the amount of $\mathrm{Cr}$ (chromium) for the CCA-3 was 7.41\% and after being burned it was $34.99 \%$, but the amount of $\mathrm{Cu}$ (copper) and As (arsenic) were almost unchanged (Cu from 16.29 to 16.69 ; As from 10.21 to $11.89 \%$ ). In a previous work (Lin et al., 2007) reported that due to the fact that CCA-3 was composed of a mixture of chromium trioxide $\left(\mathrm{CrO}_{3}\right)$, cupric oxide $(\mathrm{CuO})$, and arsenic pentoxide $\left(\mathrm{As}_{2} \mathrm{O}_{5}\right)$, the EDX results for these oxides after being burned were that the residual $\mathrm{Cr}$ from the $\mathrm{CrO}_{3}$ was $64.15 \%$, $\mathrm{Cu}$ from the $\mathrm{CuO}$ was $58.39 \%$ and As from the $\mathrm{As}_{2} \mathrm{O}_{5}$ was $36.92 \%$. This indicates that $\mathrm{Cr}$ and $\mathrm{Cu}$ from the char of the CCA preservatives was a stable element, but that $\mathrm{AS}_{2} \mathrm{O}_{5}$ was formed in a gaseous state and that it disappeared at a temperature of over $600{ }^{\circ} \mathrm{C}$. With other words, As is easily volatilized with the increase in temperature during combustion. The above results agree with the literature (Hirata et al., 1993; Kercher and Nagle, 2001; Cooper et al., 2003; Helsen and Bulck, 2005; Lee et al., 2005). For the ACQ-1, the char contained a great amount of inorganic metal elements, such as $\mathrm{Cu}(50.14 \%)$. This indicates that the main char of the ACQ-1 was $\mathrm{Cu}$, which was almost unable to be combusted toward the end of the TGA tests. The above results of the EDX analysis indicate that the char of CCA-3 includes $\mathrm{Cr}, \mathrm{Cu}$ and As amounting to about $63.57 \%$ of the residual elements. Therefore, if the disposal method of landfilling is adopted, the amounts and types of residual elements of CCA-3 need to be known.

From the results, it is concluded that the ignition point, the $\%$ of chemical ingredients and/or the heat decomposition of the preservatives may influence their thermal properties in relation to the extent and chemical nature of the smoke released during the burning process. The authors of this research, therefore, suggest that further identification of decomposition products may lead to useful results concerning the discarding process of chemical compounds by conducting principal component analysis, using combined methods, such as TGA-IR for investigating the evolved species and using EDX to analyze the char, as well as the preservatives themselves.

\section{ACKNOWLEDGEMENT}

The authors are grateful to the Kunnyih Co. Ltd., Taiwan, for providing the experimental materials. We offer our sincere appreciation to the National Science Council through Grant No. NSC 94-2313-B-415-008 for financial support.

\section{REFERENCES}

Allaby, M. 2000 Basics of Environmental Science $2^{N D}$. Routledge Australia, pp. 44-50

Aplin, G., P. Beggs, G. Brierley, H. Cleugh, P. Curson, P. Mitchell, A. Pitman, and D. Rich 2000 Global Environmental Crises Second Edition, Oxford Australia, pp. 30-60
Cooper, P. A. 1994 Disposal of Treated Wood Removed from Service: The Issues. Environmental Considerations in the Manufacture, Use, and Disposal of Preservative-treated Wood. Forest Products Society, pp. 85-99

Cooper, P. A. 2001 Analysis of Consumer Lumber Waste Management Options. Final report prepared for Wood Preservation Strategic Options Process, Manufacturers/Treaters Steering Committee and Consumer Waste Lumber Working Group

Cooper, P., T. Ung, F. Kazi and D. Qi 2003 Two Approaches of CCA Treated Wood: Extraction for Recycling and Wood Cement Composites. Presented at the AWPA Annual Meeting, Boston, MA

Connell, M. 1991 Industrial Wood Preservatives - The History, Development, Use, Advantages and Future Trends. In: Thompson R, ed. The chemistry of wood preservation. Cambridge, Royal Society of Chemistry, pp. 16-34

Cox, C. 1991 Chromated Copper Arsenate. J. of Pesticide Reform, 11(1): 2-6

Esser, P., P. Eggels and A. Voss 2000 Waste Management of Wood Products in Life Cycle Assessment. Presented at the $31^{\text {st }}$ Annual IRG Meeting, Kona, Hawaii, US IRG/WP 00-50154

Falk, B. 1997 Opportunities for the Woodwaste Resources. Forest Products J., 47(6): 17-22

Hartzell, G. E. 1996 Overview of Combustion Toxicology. Toxicology, 155: 7-23

Helsen, L., and E. Van den Bulck 1998 The Microdistribution of Copper, Chromium and Arsenic in CCA Treated Wood and Its Pyrolysis Residue Using Energy Dispersive X-ray Analysis in Scanning Electron Microscopy. Holzforschung, 52(6): $607-614$

Helsen, L. and E. Van den Bulck 2005 Review of Disposal Technologies for Chromated Copper Arsenate (CCA) Treated Wood Waste, with Detailed Analyses of Thermogravimetrical Conversion Processes. Environmental Pollution, 134: 301-314

Hirata, T., M. Inoue and Y. Fukui 1993 Pyrolysis and Combustion Toxicity of Wood Treated with CCA. Wood Sci Technol, 27: 35-47

Hsu, C. K., K. B. Cheng and J. S. Lee 2000 The Applications of the Thermal Analysis Techniques on Polymer Materials (in Chinese). J. Spinning and Weaving Engineering, 18: $43-58$

Ibach, R. E. 1999 Chapter 14 Wood preservatives. Wood Handbook - Wood as an Engineer Material. Forest Products Society, pp. 14-2 - 14-9

Jang, Y. M. 1997 Waste Processing (in Chinese). WEN-JING Book Corp. (Taipei), pp. 49-85

Kercher, A. K. and D. C. Nagle 2001 TGA Modeling of the Thermal Decomposition of CCA Treated Lumber Waste. Wood Science and Technology, 35: 325-341

Kobayashi, N., M. Thikae and Y. Tominaga 2000 The properties and manufacture of renewable board from particleboard (in Japanese). In "Abstracts of the 50 $0^{\text {th }}$ Annual Meeting of the Japan wood Research Society", Japan Wood Research Society, Kyoto, Japan, pp. 285

Kotz, R., H. Gerischer and C. W. Tobias (Eds.) 1990 Advances in Electrochemical Sciences and Engineering, $V C H$ 1, Weinheim

Kuwahara, M. 1996 Wood and Environmet (in Japanese). Kaiseisya Japan, pp. 29-32

Ladomersky, J. 2000 Emission analysis and minimization from the wood waste combustion. Drevarsky Vyskum, 45(4): 33-44

Lee, H. L., T. C. Shiah, F. L. Hsu and S. J. Lin 2005 Effects of New Waterborne Wood Preservatives on the Durability and Thermal Properties of Wood. Taiwan J. For Sci., 20(2): $139-156$

Lin, H. C., T. Ohuchi and Y. Murase, 2004 Estimating Thermal Behavior and Analyzing Evolved Species of Adhesives through Thermogravimetric Analysis combined with Spectrometric Techniques. J. of Fac. Agr., Kyushu Univ., 49(2): 449-459 
Lin, H. C., T. Ohuchi, Y. Murase, T. -C. Shiah, L. T. Gu, M. J. Lee and Y. D. Wu 2006 Application of TGA and EDX Analysis to Evaluate the Process of Preservative-Treated Woods. J. of Fac. Agr., Kyushu Univ., 51(2): 337-344

Lin, H. C., T. Ohuchi and Y. Murase 2007 Analysis of Combustion Emissions and Char from CCA- and ACQ-Treated Woods. J. of Fac. Agr., Kyushu Univ., 52(1): 91-98

Sanders, J. G. and H. L. Windom 1980 The Uptake and Reduction of Arsenic Species by Marine Algae. Environment, 10: $555-567$

Sanders, J. G. and G. F. Riedel 1987 Control of Trace Element Toxicity by Phytoplankton. Recent Adv Phytochem, 21: 131-149

Solo-Gabriele, H. M., T. G. Townsend and J. Schert 2003 Environmental Impacts of CCA Treated Wood: A Summary from Seven Years of Study Focusing on the US Florida Environment. Presented at the 34th Annual IRG Meeting, Brisbane, Australia, IRG/WP 03-50205

Statheropoulos, M. and S. A. Kyriakou 2000 Quantitative thermogravimetric-mass spectrometric analysis for monitoring the effects of fire retardants on cellulose pyrolysis. Analytica Chimica Acta., 409: 203-214
Takahashi, T., M. Suzuki, and Nakao, T. 1995 Wood Science Series 5 Environment (in Japanese). Kaiseisya Japan, pp. $7-15$

Weis, J. S. and P. Weis 1922a Transfer of Contaminants from CCA-Treated Lumber to Aquatic Biota. J Exp Mar Biol Ecol, 161: $189-99$

Weis, J. S. and P. Weis 1922b Construction Materials in Estuaries Reduction in the Epibiotic Community on Chromated Copper Arsenate (CCA)-treated wood. Mar Ecol Prog Series, 83: $45-53$

Weis, J. S. and P. Weis 1996 Reduction on Toxicity of Chromated Copper Arsenate (CCA)-Treated Wood as Assessed by Community Study. Mar Environment Res, 41: 15-25

Weis, J. S. and P. Weis 1999 Accumulation of Metals in Consumers Associated with Chromated Copper Arsenate-Treated Wood Panels. Mar Environment Res, 48: 73

Zhu, S. and W. Shi 2001 Hyperbranched polyurethane acrylates containing phosphate as radiation curable flame-retardant coating material. Conference Proceedings, China, pp. $108-114$ 